\title{
IAMJ
}

INTERNATIONAL

AYURVEDIC

MEDICAL JOURNAL

Review Article

ISSN: 2320-5091

Impact Factor: 6.719

\section{ROLE OF MANSIK BHAVAS ON IMMUNITY W.S.R. TO COVID-19}

\author{
Sanjay Kumar Bhatnagar ${ }^{1}$, Rajesh Kumar Sharma ${ }^{2}$, Dinesh Chandra Sharma ${ }^{3}$ \\ ${ }^{1}$ P.G. Scholar, P.G. Department of Kriya Sharir, DSRRAU, Jodhpur, Rajasthan, India \\ ${ }^{2}$ Professor and H.O.D., P.G. Department of Kriya Sharir, DSRRAU, Jodhpur, Rajasthan, India \\ ${ }^{3}$ Associate Professor, P.G. Department of Kriya Sharir, DSRRAU, Jodhpur, Rajasthan, India
}

Corresponding Author: bhatnagarsanjay95@gmail.com

https://doi.org/10.46607/iamj0109072021

(Published Online: July 2021)

Open Access

(C) International Ayurvedic Medical Journal, India 2021

Article Received: 02/07//2021 - Peer Reviewed: 05/07/2021 - Accepted for Publication: 06/07/2021

Check for updates

\begin{abstract}
The world was confronted with an illness 'COVID-19', caused by the novel coronavirus SARS-CoV-2. This novel coronavirus is highly contagious and in just a few months has become a serious threat to human health all over the world. It was declared as a Public Health Emergency of International Concern by the end of January 2020 and a pandemic in March 2020. In addition to the public health challenges, this pandemic has created another parallel pandemic of mental health problems. There are many relations of doing panic and getting the disease and the possibility of Mansik Bhavas like fear (Bhaya), anger (Krodha), grief (Shoka) and not follow Sadvrutta can be the cause or precipitating factor of infection to any person. Ayurveda and modern point of view agree to the statement that different Mansik Bhavas like Bhaya, Krodha, Shoka and not follow Sadvrutta etc. can lead to or can act as Hetu for many diseases like COVID-19 etc. and hence there is the existence of a relation between these Mansik Bhavas and Vyadhi Utpatti. Furthermore, the existing mental health problems have also been seen to exacerbate owing to this pandemic. The mental health problems are both seen among the community members and the healthcare providers who are at the continuous forefront of service provision in healthcare settings. The best way of preventing COVID-19 infection is by enhancing an individual's body immunity. Some of the principles could be useful in mitigating the mental health issues that the current world is grappling with owing to COVID-19. In this review article, we will understand the Role of Mansik Bhavas on immunity to COVID-19 with different references given in Ayurvedic texts, modern texts and articles.
\end{abstract}


Keywords: Ayurveda, COVID-19, Mansik bhavas (Bhaya, Krodha, Shoka and Sadvrutta), Immunity.

\section{INTRODUCTION}

COVID-19 is a disease caused by SARS-CoV-2 that can trigger what doctors call a respiratory tract infection. It can affect your upper respiratory tract (sinuses, nose and throat) or lower respiratory tract (windpipe and lungs). It spreads the same way other coronaviruses do, mainly through person-to-person contact. Infections range from mild to deadly. SARS-CoV-2 is one of seven types of coronaviruses, including the ones that cause severe diseases like the Middle East respiratory syndrome (MERS) and sudden acute respiratory syndrome (SARS). The other coronaviruses cause most of the colds that affect us during the year but aren't a serious threat for otherwise healthy people. ${ }^{1}$ The mainstay in the management of corona viral infections has been supportive care, nutrition and preventing secondary infections in the absence of any antiviral agent or vaccine. Enhancing the body's natural defence system (immunity) plays an important role in maintaining optimum health. Ayurveda is a system of lifestyle medicine that works to improve one's vitality or modulating immunity and can, therefore, be used as a preventive approach. Several measures can be used to improve immunity against infections. This may be useful in this current scenario where we are facing a COVID-19 pandemic. ${ }^{2}$ Ayurvedic literature reiterates the interrelationship between the body and mind in its approach to illness as well as health at many places. Though the vitiated doshas, dhatus and malas remain the physiological basis of illness, the illness itself is a more complex psychosomatic phenomenon according to Ayurveda. Here I should draw the attention of the reader to a lesserknown Ayurveda concept of 'mansika' doshas. The body (sarira) is the substratum (adhishtana) of somatic (saririka) doshas. When the three somatic doshas are deranged, through an interaction of the doshas, dhatus and malas, somatic illness arises. Likewise, the mind (manas) is the substratum (adhishtana) of the psychological (manasika) doshas (rajas and tamas). Due to 'prajnaparadha' or erroneous judgment, the two psychological doshas predominate and cause various afflicting emotions or thoughts like lust (kama), greed (lobha), delusional thinking (moha), jealousy (irsya), arrogance (mada), grief (shoka), anxiety (Chinta), and fear (bhaya). Ayurveda views these afflictions too as mental afflictions though conventionally they are not considered as mental diseases. These afflictions can lead to mental illness once they cross a threshold. However, one has to bear in mind that the classification of the diseases as well as doshas into somatic (saririka) and psychological (manasik) is not watertight compartmentalization as many illnesses reveal an underlying interlinked mind-body interaction. Somatic doshas (vata, pitta and kapha) are influenced by the psychological doshas just as psychological doshas are influenced by the somatic doshas. For instance, worry and grief increase vata, anger increases pitta, too much pleasure increase kapha. ${ }^{3}$

\section{MANSIK BHAVAS AND THEIR EFFECTS ON BODY}

Bhaya (Fear): It is a condition precipitated by the dreadful act. It develops due to facing the unwanted situation. Rajodosha is mainly involved. Bhaya is a human emotion that makes a person incapable of doing anything as a result of which mana of a person becomes restless. An increase in Bhaya further leads to an increase in Vatadosha which can lead to diseases. The victim of Bhaya can suffer from Diarrhoea. Acharya Charaka has mentioned Bhayaja Atisara among its 6 types. Its intensity is examined by $\mathrm{Vi}$ shada.$^{4}$ In fear the punishment centre of the limbic system is activated. It turns on the autonomic response of fight-or-flight response. Stimulation of a thin zone of periventricular nuclei of thalamus, located immediately adjacent to the third ventricle usually leads to fear. The fear reaction starts in the brain and spreads through the body to make adjustments for the best defence or flight reaction. The fear response starts in a region of the brain called the amygdala. For example, the amygdala activates whenever we see a human face with an emotion. This reaction is more pronounced with anger and fear. A threat stimulus such as the sight of a predator triggers a fear response in the amygdala 
which activates areas involved in preparation for motor functions involved in fight or flight. It also triggers the release of stress hormones and the sympathetic nervous system. ${ }^{5}$

Krodha (Anger): One of the evils found within the human mind. Krodha originates from the rajo guna and the main feature is to harm others. It vitiates vata and pitta and produces symptoms accordingly. This causes daha in the whole body and stimulation of mana, further causing diseases. ${ }^{6}$ Anger is experienced in our bodies as well as in our minds. When we are angry, series of physiological events can occur. The physiology of anger is connected to Amygdala / Limbic system, Hypothalamus, Pituitary gland, Adrenal gland. The amygdala is the part of the brain, responsible for identifying threats to our well-being and for sending out an alarm when threats are identified. If the incoming data is enough to trigger an emotional charge the amygdala can override the cortex which means the data will be sent to the limbic system. This reactive incident is known as amygdala hijacking. When the amygdala is hijacked, a flood of hormones like adrenalin or noradrenaline is released that can cause physical and emotional alarm. Due to the impact of this hormonal flush, the person is usually out of control. The impact can last for several hours to days. Stress hormones are active for about 4 hours which is known as the amygdala hijack hangovers. The first spark of anger activates the amygdala. The amygdala activates the hypothalamus. The hypothalamus signals the pituitary gland by discharging corticotropin-releasing hormone $(\mathrm{CRH})$. The brain releases neurotransmitter catecholamines. Then the pituitary activates the adrenal gland by releasing adrenocorticotropin hormone (ACTH). The adrenal glands secrete stress hormones like cortisol, adrenaline and noradrenaline. Elevated cortisol kills neurons in the hippocampus and disrupts the creation of new ones. Suppressed activity in the hippocampus weakens short-term memory. Hormone serotonin is considered the happy hormone. Too much cortisol will decrease serotonins levels. A decreased serotonin can make feel anger and pain more easily. Increase aggressive behaviour and lead to depression. ${ }^{7}$
Shoka (Grief): It is a mental state precipitated by the loss of objects which are more beloved and in it rajo dosha is mainly involved. Vata dosha aggravates first then pitta dosha aggravation. The distress caused by shoka can lead to many ill effects. Continuous exposure to shoka for a longer period can cause different physical diseases. $^{8}$

The old English word for grief, heartsarnes, literally means soreness of the heart. Grief frequently leads to changes in the endocrine, immune, autonomic nervous, and cardiovascular systems; all of these are fundamentally influenced by brain function and neurotransmitters. It is well known that adrenal cortical activity has the effect of reducing circulating lymphocytes and increasing thymic involution, resulting in diminished immune function. To put it simply, the brain produces a hormone called adrenocorticotrophic (ACTH) that prepares the body for battle. Then, the ACTH goes from the pituitary gland to the adrenal gland that causes a chemical reaction producing cortisol. Cortisol is known as the "stress hormone." Prolonged, high levels of this hormone have harmful and stressful physical effects on the body. So, the longer the stress from grief continues, the more ACTH is produced, which means more stress hormones as well. Abnormally increased amounts of this hormone also cause problems with the production of white blood cells. Without the normal production of these cells, our bodies cannot fight germs as well, increasing the likeliness of getting sick. ${ }^{9}$

Sadvrutta: Charak Samhita described Sadvrutta comprising two words "Sat" meaning good and "Vrtta" meaning regimen. The detailed description about Sadvrutta proposes to mingle with good friends and peer, acquire happiness and aloofness from bad impacts and avoid an atheist and greed ${ }^{10}$ Let us now consider this concept in the context of COVID-19 in which it is evident from several studies that people mostly tried to adhere to activities that they observed from their nearest environment. In this context, the nearest environment could be the e-environment such as social media and the Internet, as people were mostly locked down in their houses and could only connect to their near and dear ones virtually. The emotional 
manifestation, fear, anxiety, depression and panic state is the result of such access. People having the above-mentioned mental health problems could ward off the same if they follow the principles of Sadvrutta meaning following $a$ good regimen. Following a good regimen could also help them avoid the exhibition of stigmatizing behaviour in the community. People should follow the right information from appropriate sources and should also get in touch with people who are the health experts who could guide them and allay their anxiety through psychosocial support and counselling. This is all about Sadvrutta, the good regimen, linking with "good" helps develop good behaviour. This concept has been applied to many different settings to understand health behaviour and the same can also be applied as an intervention measure to ward off mental health problems originating from COVID-19. ${ }^{11}$ PSYCHONEUROIMMUNOLOGY AND COVID19

Furthermore, the concept of "psychoneuroimmunology" and "meaning response" holds significant value in fighting the mental and organic problems due to COVID-19. Psychoneuroimmunology talks about an intimate relationship between the nervous, endocrine, and immune systems and explains the mechanism of an immune response to infection through stress, fear and emotional disorders. Similarly, the concept of "meaning response" contrary to "placebo response" describes that an individual's response does not only depend on the pharmacological properties of a drug but on the meaning, they ascribe to this treatment. Thus, the advisory on the usage of Ayurvedic preparations to boost immunity could be a combination of the effect of "meaning response" and the interactions of nervous, endocrine, and immune systems in the human body. ${ }^{12}$

IMPACT OF COVID-19 ON MENTAL HEALTH

Public health emergencies and pandemic situations can have severe mental health implications at individual and family levels. These public health emergencies can lead to emotional distress, fear, grief and anxiety among the sufferers and their family members. These feelings of distress fear, grief and anxiety can also occur to people who are not even at high risk of getting sick in the face of a virus, with which the common man is not familiar. ${ }^{13}$ At individual and community levels, it can precipitate new mental health problems without preexisting conditions and with preexisting conditions, it can aggravate causing distress, fear, grief to the individual caregivers. Regardless of exposure to infection, people may land up in a panic situation of getting ill, dying, helpless, blaming and labelling other people of spreading the infection leading to a mental breakdown. ${ }^{14}$ Several types of mental health problems have been reported that range from fear, grief, depression, anxiety, panic attacks, somatic symptoms, posttraumatic stress disorder, delirium, psychosis, and even suicide. ${ }^{15}$ Many countries have reported suicide cases during COVID-19 pandemics including India. Health-care workers are also developing mental health problems throughout the globe. This is primarily linked with their protracted working hours in healthcare settings caring for the COVID-19 cases. These healthcare professionals have a higher risk of getting the infection and in short, they are exposed to a protracted source of distress that exceeds their coping skills. Health-care professionals have been found to display a heightened level of stress, fear, depression and anxiety not only because of getting infected themselves but also because of their loved ones and the children. Keeping a balance between professional responsibilities, personal care and altruism may cause conflict and dissonance among many healthcare professionals during such emergencies. ${ }^{16}$

\section{IMMUNITY (OJAS) AND COVID-19}

Enhancing the body's natural defence system (immunity) plays an important role in maintaining optimum health. ${ }^{17}$ Ayurveda is a system of lifestyle medicine that works to improve one's vitality or modulating immunity and can, therefore, be used as a preventive approach. In Ayurveda, we find all the fundamentals of immunity and their utility to prevent and cure the disease respectively. Vyadhikshamatwa (immunity) is illustrated as the power of resistance capable enough to check the progress occurrence or recurrence of the disease. 


\section{The concept of immunity comprises two factors: ${ }^{18}$}

1. Vyadhi uttpadha prathibhandhakatvam - Resistance to the formation of diseases and resistance to causative factors of diseases. Maybe it is correlated with sahajabala or innate immunity.

2. Vyadhi bala virodhitvam - Capacity to prevent the spread of diseases in the body and capacity of body blocking the diseases in its primary stage is called immunity. Ojas is considered responsible for Vyadhikshamatva (immunity). Due to the loss of Ojas, persons are susceptible to other intercurrent diseases and superadded infections like COVID-19. Hence, an adequate exposition of the concept of Ojas concerning immunity is essential.

\section{Ojas And Its Role In Body Resistance ${ }^{19}$}

In Ayurveda, it is the ojas that has been considered to play an important role in the defence mechanism of the body. As regards the kinds of Ojas, Hemadri says that the followers of medical science take the term ojas in following multiple senses.

1. Dhatu Tejo rupa Ojas is present in all the tissues of the body. This indicates the immune mechanisms present at the tissue level like those due to tissue macrophages, mast cells and other white blood cells of the tissue pool.

2. Rasatmaka Ojas is the form of Ojas, which moves along with the rasadhatu and circulates all over the body through the cardiovascular system. All WBCs and other substances related to the immune system like those of the complement system and antibodies circulating in the intravascular compartment can be included in this.

3. Shukramala rupa Ojas is the form of Ojas which enters the fetus to protect during intrauterine life. Immunoglobulins, which cross the placental barrier to enter the fetal circulation, can be included under this category.

4. Jivasonita rupa ojas is specific for blood cells. All hypersensitivity reactions involving blood cells can be assumed to be resulting from the malfunctioning of this form of Ojas.

\section{DISCUSSION}

Mansika bhava adversely affect not only the mind but also almost all the systems of the body, which may sometimes endanger the life of the individual. The root cause of impaired Atma-indriya-Artha samyoga is the pragyaparadha. Due to the lack of intelligence, memory and willpower, man is prone to commit intellectual errors. It will vitiate all the doshas especially vata, which in turn vitiates trigunas. Vitiation of tridoshas and trigunas causes impairment of all mental and physical functions. All these effects result in the development of diseases. This COVID 19 pandemic can be correlated with the concept of $J a$ napdodhwamsa mentioned in Charak Samhita. The causes of Janapadodhwamsa are further classified into two - (a) those that occur due to natural causes and (b) those that occur due to man-made causes. Both of these may further be classified into four- This COVID 19 pandemic can be correlated with the concept of $\mathrm{Ja}$ napdodhwamsa mentioned in Charak Samhita. The causes of Janapdodhwamsa are mainly classified into four main types-vitiation of land, air, water, and climate, which are responsible for the incidence of epidemics and pandemics, and transcend demographic dynamics Acharya Charaka mentioned that Pradnyaparadh is the main factor which is responsible to do Adhrama by an individual i.e., not following the duty to the community, also Pradnyaparadh itself led person not to follows Dinacharya (daily regimen) and Ritucharya (seasonal regimen) which further hampered the immunity of an individual. The immunity of the body always plays role in defending the body from different diseases. Immunity is always the first line of defence and always try to protect the body. The occurring of any disease can be an indicator of the failure of the immune response. Different emotional behaviours (Mansik Bhavas) hence lead to disturbance in the immunity of the body and causes the disease.

\section{CONCLUSION}

Ayurveda in detail enumerates epidemics, infections their modes of transmission and tools for management by keeping in mind the person centre holistic approach; hence, it is necessary to evaluate the 
COVID-19 pandemic through the lens of Ayurveda and find effective integrative approaches to its management. The primary aim of Ayurveda is to prevent diseases. This prevention of diseases is achieved by the proper maintaining of the body immunity. The best way of preventing COVID-19 infection is by enhancing an individual's body immunity. Ojas is considered responsible for Vyadhikshamatva (immunity). Due to the loss of Ojas, persons are susceptible to other intercurrent diseases and superadded infections like COVID-19. Hence, an adequate exposition of the concept of Ojas about immunity is essential. According to Ayurveda, measures to maintain or upgrade the natural body resistance are daily regimen, seasonal regimen, sadvritta, balanced diet, and rasayana chikitsa.

\section{REFERENCES}

1. https://www.webmd.com/lung/coronavirus

2. Lu X, Chen Y, Bai B, Hu H, Tao L, Yang J, et al. Immune responses against severe acute respiratory syndrome corona virus induced by virus-like particles in mice. Immunology 2007; 122:496-502).

3. https://karmicrhythms.com/healing-from-the-source-2the-somatic-psychological-karmic-and-metaphysicalaspects-of-illness/

4. Charak Samhita, by Agnivesha with Ayurved dipika commentary of Chakradatta Edited by Vaidya Yadav Ji Trikamji Chaukhamba Sanskrit Sansthan, Varanasi, edition 5th 2001, Vimanasthana 4/8.

5. https://www.smithsonianmag.com/science-nature/what-happens-brain-feel-fear180966992/\#HZ3YRwOXJ6UhXBWs.99

6. Charak Samhita, by Agnivesha with Ayurved dipika commentary of Chakradatta Edited by Vaidya Yadav Ji Trikamji Chaukhamba Sanskrit Sansthan, Varanasi, edition 5th 2001, Vimanasthana 4/8.

7. http://www.iamj.in/posts/2019/images/upload/1324_1327_1.pdf

8. Byadgi P.S, Pandey A.K. Manas Roga Prakarana, Kayachikitsa Vol.3. 1st edition. Varanasi: Chaukhambha Sanskrit Sansthan; 2014.

9. https://web.frazerconsultants.com/2017/06/physicaleffects-of-grief-on-the-body-and-how-to-cope/

10. Charak Samhita, by Agnivesha with Ayurved dipika commentary of Chakradatta Edited by Vaidya Yadav Ji Trikamji Chaukhamba Sanskrit Sansthan, Varanasi, edition 5th 2001, Sutrasthana 8/18-27.
11. https://www.ijournalhs.org/temp/indianjhealthsci14138-1601926_042659.pdf

12. Rajkumar R P. Ayurveda and COVID-19: Where psychoneuroimmunology and the meaning response meet. Brain Behav Immun 2020; 87:8-9.

13. Montemurro N. The emotional impact of COVID-19: From medical staff to common people. Brain Behav Immun 2020; 87:23-4.

14. Hall RC, Hall RC, Chapman MJ. The 1995 Kikwit Ebola outbreak: Lessons hospitals and physicians can apply to future viral epidemics. General Hosp Psychiatry 2008; 30:446-52.

15. Gunnell D, Appleby L, Arensman E, Hawton K, John A, Kapur N, et al. Suicide risk and prevention during the COVID-19 pandemic. Lancet Psychiatry 2020; 7:468-71.

16. McAlonan GM, Lee AM, Cheung V, Cheung C, Tsang KW, Sham PC, et al. Immediate and sustained psychological impact of an emerging infectious disease outbreak on health care workers. Can J Psychiatry 2007; 52:241-7.

17. Lu X, Chen Y, Bai B, Hu H, Tao L, Yang J, et al. Immune responses against severe acute respiratory syndrome corona virus induced by virus-like particles in mice. Immunology 2007; 122:496-502.

18. Charak Samhita, by Agnivesha with Ayurved dipika commentary of Chakradatta Edited by Vaidya Yadav Ji Trikamji Chaukhamba Sanskrit Sansthan, Varanasi, edition 5th 2001, Sutrasthana 28/6.

19. http://www.journayu.in/temp/JAyurveda144851793838_045858.pdf

\section{Source of Support: Nil \\ Conflict of Interest: None Declared}

How to cite this URL: Sanjay Kumar Bhatnagar et al: Role of Mansik Bhavas On Immunity w.s.r. to Covid-19. International Ayurvedic Medical Journal \{online\} 2021 \{cited July 2021\} Available from: http://www.iamj.in/posts/images/upload/1322_1327.pdf 